\title{
Histomorphology and Histochemistry of Liver of Adult Bakerwali and Non-descript Goats of Jammu, India
}

\author{
Lovish Sethi, Shalini Suri, Kamal Sarma and Jasvinder Singh Sasan" \\ Division of Veterinary Anatomy, F.V.Sc \& A.H., SKUAST-J, R.S. Pura, Jammu, UT of Jammu E Kashmir, INDIA \\ "Corresponding author: JS Sasan; E-mail: jssasan216@gmail.com
}

Received: 23 April, 2021

Revised: 17 May, 2021

Accepted: 20 May, 2021

\begin{abstract}
The present study was conducted on the histomorphology and histochemistry of liver of Bakerwali and non-descript goats. Histologically hepatic lobules, portal lobules and liver acini were observed. Hepatic lobules were hexagonal with clear boundaries in Bakerwali goat whereas in non-descript goats, the interlobular connective tissue was minimal making it difficult to recognize the lobule as hexagonal. Portal lobule was triangular, functional unit of liver consisting of parenchyma of three adjacent hepatic lobules. Liver acini were diamond-shaped area having three zones. Hepatocytes of zone 3 were darker stained as compared to zone 1 and 2 in both the breeds. Hepatocytes were arranged in radiating cords (hepatic cords) approximately one to two cells in thickness. This pattern of radiating cords was seen prominently in Bakerwali goats but in non-descript goats these cords anastomosed with one another showing interconnected network of hepatic arch, enclosing spaces "the sinusoids". The histochemical distribution of mucopolysaccharides, proteins and sudanophilic lipids didn't vary among Bakerwali and nondescript goats but reactions was variable in different parts of liver parenchyma.
\end{abstract}

\section{HIGHLIGHTS}

(O Interlobular connective tissue was abundant in Bakerwali goat as compared to non-descript goats making hepatic lobules clearly recognizable in Bakerwali goat.

(0 Radiating pattern of hepatocytes was more prominent in Bakerwali goat.

Keywords: Bakerwali goat, hepatocyte, histochemistry, histomorphology, liver

Goats are important livestock species in developing countries and referred to as "Poor Man's Cow" in India and 'wet nurse' of infants in Europe (Iqbal et al., 2008). Goat husbandry has been playing an important role in the economy of our country with special reference to milk, meat, manure and hides production (Arora et al., 2013). A number of large and small economically weaker farmers rear goat for their livelihood (Singh et al., 2006). Estimated livestock population of the Union Territory of Jammu and Kashmir state is 20.18 lakh goats, goats population has increased by $10.14 \%$ from previous survey. Of these, 11.3 lakh are Bakerwali goats, constitute about $50 \%$ of total goat population of UT of J\&K (Gupta and Bakshi, 2009). Bakerwali or Bakerwali goat (Capra hircus) belongs to family Bovidae and subfamily Capridae. Bakerwali goat is a breed of Northern Himalayan region breed with white, brown or black with white markings \& fine silky hair (about 10-12 cm long). Bakerwali goats have long hair and are horns. Tail is short with tuft of hairs and legs are stout (Gupta and Bakshi, 2009). Moreover, the Bakerwali goat is known for its habit to migrate over long distances (Sarma et al., 2012) whereas non-descript goat is stationary. During migration, goats are exposed to many physical and environmental stresses i.e. change in temperature and humidity ( $\mathrm{Hu}$ et al., 2020).

How to cite this article: Sethi, L., Suri, S., Sarma, K. and Sasan, J.S (2021). Histomorphology and histochemistry of liver of adult Bakerwali and non-descript goats of Jammu, India. J. Anim. Res., 11(3): 487-495. Source of Support: None; Conflict of Interest: None क क 
The liver (hepar) is an extremely important organ in the body of mammals and vertebrates as it performs functions essential for life. It is the largest internal gland of the body, constituting 1-2\% of total adult body weight (Frandson et al., 2009). The liver is the "Jack-of-all-trades" of the body, established in strategic position in the vascular system, obligatory to the digestive system (Culling, 1974). The liver has numerous functions including production of bile and protein, fat and carbohydrate metabolism. The size of the liver varies with respect to age, weight and function. It is much heavier in young animals than older animals as it atrophies with age (Dyce et al., 2010).

Histomorphological and histochemical information about liver of Bakerwali goat is meager. Hence, present study was planned with the objective to study the histomorphology and histochemistry of the liver of adult Bakerwali goats and compare it with non-descript goats.

\section{MATERIALS AND METHODS}

The present study was carried out in the Division of Veterinary Anatomy, F.V.Sc \& A.H., SKUAST-Jammu. Liver samples of apparently healthy adult Bakerwali goats were collected from slaughter houses of Nagrota of J\&K UT and non-descript goat liver were collected from slaughter houses in and around Jammu city. Six samples from each goat breed were collected. Immediately after collection, the liver were promptly brought to laboratory in ice and subjected for recording the gross morphology and biometrical parameters. The samples from each breed were preserved in neutral buffered formalin for histomorphological and histochemical studies.

Small pieces of liver tissue $(2 \mathrm{~mm})$ samples were collected from different areas of liver lobes (dorsal, middle and ventral), portal area, at the level of oesophageal notch, caudate lobe and hepatic lymph node from each group and fixed in neutral buffered formalin solution, were processed for making paraffin block (Luna, 1968). Tissue sections of $5 \mu \mathrm{m}$ thickness were obtained from these blocks on clean glass slides.

For routine histomorphology, tissues sections were stained with Haematoxylin \& Eosin stain. For connective tissue fibres, stains used were Mallory's stain \& Verhoeff's (collagen fibres), Von Gieson stain (elastic fibres) and Gomori's stain (reticular fibres). For localizing the different histochemical moieties viz; neutral mucopolysaccharides and glycogen, Periodic Acid Schiff's and Best Carmine stains were used. For demonstration of cholesterol and lipids, sections were stained with Shultz method and Sudan black B, respectively (Luna, 1968).

\section{RESULTS AND DISCUSSION}

\section{Histomorphology}

In the present study, the liver of both the breeds was covered by two distinct layers i.e outer peritoneal layer and inner connective tissue covering (Fig. 1) as earlier reported by Pareek (2000) in Magra sheep. The outer peritoneal layer covered each lobe of liver of both Bakerwali and nondescript goats except at places where it was reflected as ligaments and dorso-caudally a small area where the organ was directly related to the diaphragm. Similar observations were made earlier by Pareek (2000) in Magra sheep. The inner connective tissue covering was in the form of a capsule i.e. Glisson's capsule as reported by Trautmann and Fiebiger (1957) in cattle, Bamaniya (2013) in Marwari goat and Rashad et al. (2017) in buffalo. The liver was encapsulated with capsule which comprised of mainly collagen (Fig. 2) and reticular fibres irrespective of the breed as also reported by Modekar et al. (2003) in goats, Bamaniya (2013) in Marwari goat and Thakur (2020) in buffalo. Few fibroblasts were also observed in between these fibres (Fig. 3). From the capsule connective tissue extended into the liver lobes, as interlobular connective tissue, to surround individual liver lobules and support the vascular and bile duct systems. The connective tissue fibers comprised of loosely arranged collagen fibres and reticular fibers forming network within parenchyma. The reticular fibers also formed a delicate framework around the hepatocytes and sinusoids as also observed earlier by Pareek (2000) in Magra sheep. The fine collagenous fibers surrounded each hepatocyte and thick collagenous fibres were also seen around bile ductules. The interlobular connective tissue was very less in non-descript goats. The interlobular connective tissue (collagen and elastic fibres) were seen surrounding the lymph vessels, branches of the hepatic artery, branches of the portal vein and a bile duct throughout section of liver as also reported by Thakur (2020) in buffalo. 

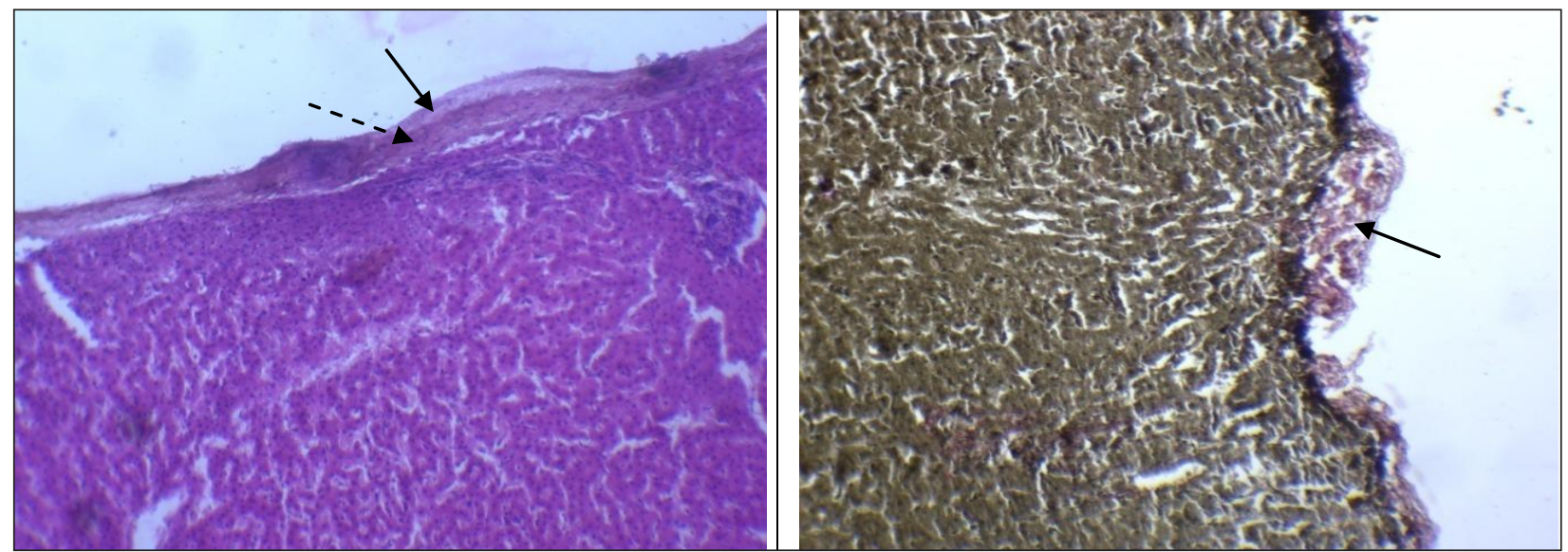

Fig. 1: Photomicrograph of liver showing outer peritoneal layer (arrow) and inner connective tissue covering (dotted arrow) of

Fig. 2: Photomicrograph of liver showing collagen fibers (arrow) capsule of liver in adult Bakerwali goat. H\&E, 100X

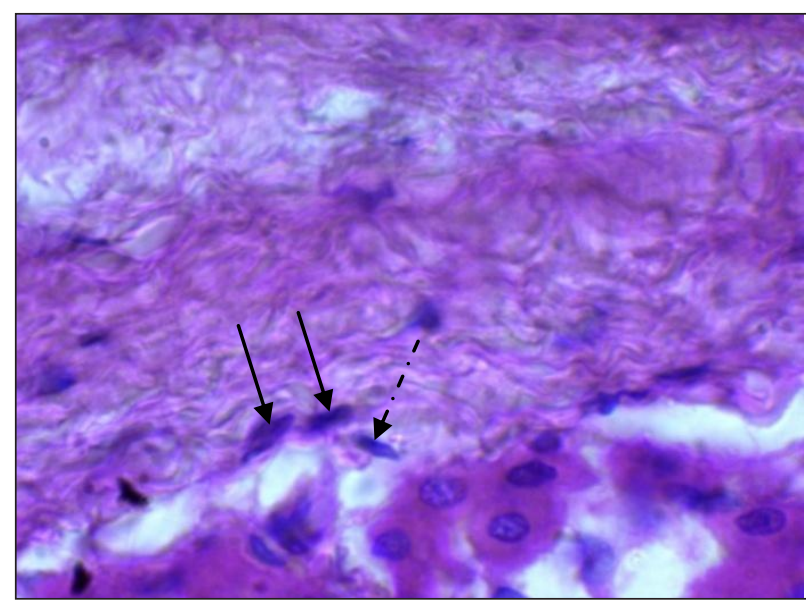

Fig. 3: Photomicrograph of liver showing fibroblasts (arrow) and fibrocytes (dotted arrow) within the connective tissue covering of liver in adult Bakerwali goat, H\&E, 1000X

The hepatic lobules formed the anatomical structural unit of the liver in both the breeds under study and were present throughout the parenchyma of liver as also reported by Thakur (2020) in buffalo. The lobules were polyhedral or prismatic in outline (Fig. 4) in both the breeds. Similar observations were made by Modekar et al. (2003) in goats and Madhan and Raju (2014) in sheep, goat and cattle. However, Khan et al. (1989) observed irregular shaped liver lobules with few hexagonal shaped lobules in goat. The hepatic lobules were easily recognized in Bakerwali goat whereas in non-descript goats the interlobular connective tissue was minimal making it difficult to recognized the hepatic lobules (Fig. 5). Prunescu et al.

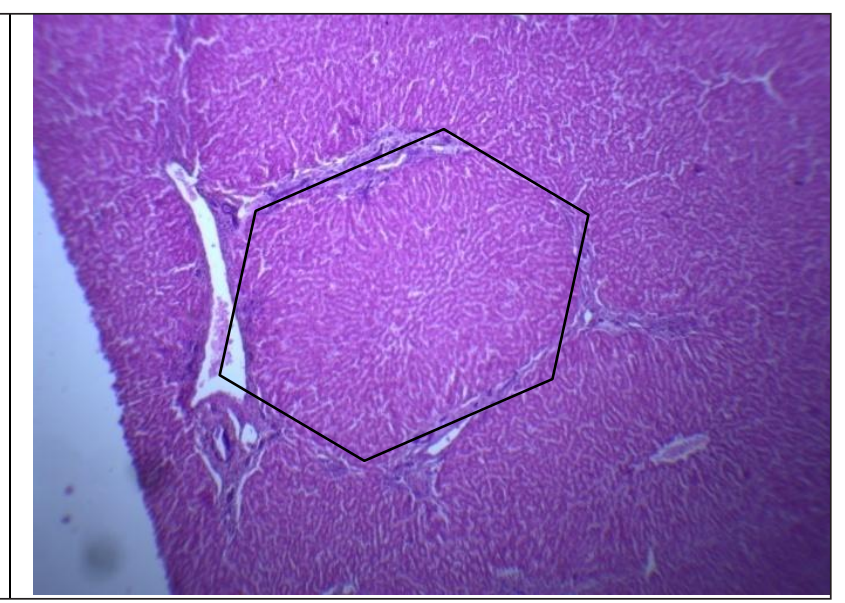

Fig. 4: Photomicrograph of liver showing distinct hepatic lobule polyhedral prismatic in outline in adult Bakerwali goat, H\&E, $40 \mathrm{X}$

(2002) also showed no connective septa around the hepatic lobules in liver of European bison. In present study, each lobule had central vein in the centre and peripheral portal area (Fig. 5) irrespective of the breed. The number of central veins in a section indicated the number of lobules. An anastomosing network of bile canaliculi, formed by the apposed cell membranes of hepatocytes was present throughout the laminae as reported by Mariappa (1981) in calves. Various blood vessels filled with blood and ducts filled with fluid were also seen in hepatic lobules.

In both Bakerwali and non-descript goats, the portal lobule was functional unit of the liver. It was a triangular area consisting of the parenchyma of three adjacent hepatic 

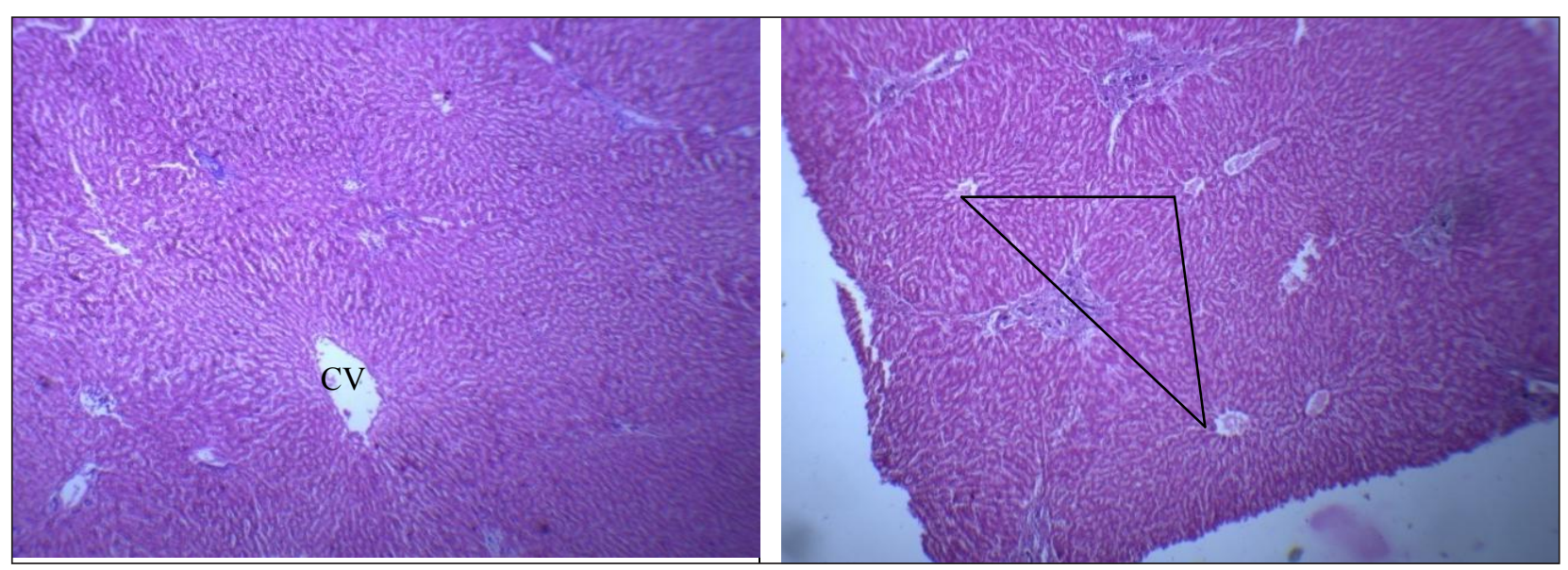

Fig. 5: Photomicrograph of liver showing indistinct hepatic Fig. 6: Photomicrograph of liver showing triangular portal lobule lobule with central vein (CV) in senile non-descript goat, H\&E, with central veins at corners in adult Bakerwali goat, H\&E, 40X $40 \mathrm{X}$
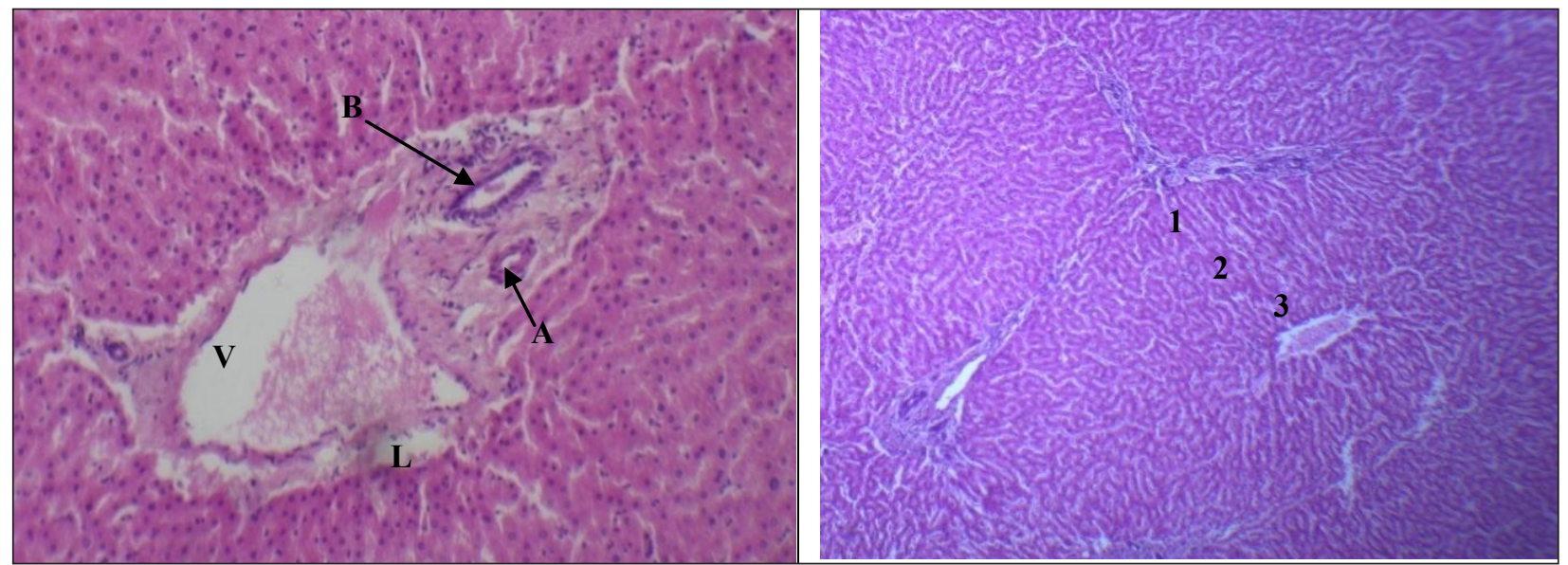

Fig. 7: Photomicrograph of liver showing portal area showing portal vein $(\mathrm{V})$, hepatic arteriole (A), bile ductile (B) and lymph vessels (L) in adult Bakerwali goat, H\&E, 100X

lobules that was drained by the bile ductule in the portal canal (Fig. 6). Similar observations were made Modekar et al. (2003) in goats. The group of the portal vein, hepatic arteriole, bile ductule and lymph vessels appeared at the each angle of hexagonal hepatic lobule and in centre of portal lobule (Fig. 7). It was supported by loose areolar connective tissue. The collagenous fibers encircled the portal veins and the hepatic arterioles and the elastic fibers invested the arterioles and the bile ductile predominantly in both Bakerwali and non-descript goats.

The liver acinus was a diamond-shaped area in both the breeds and comprised of hepatic parenchyma of parts of two classic lobules. It presented three ill-defined zones irrespective of the breed (Fig. 8). Zone 1 which was nearest to the vascular axis of liver acinus, was metabolically most active from where the hepatocytes receive excellent nutrient and oxygen supply. Also these cells were first to be exposed to toxins entering into the liver. The second zone i.e. zone 2 was intermediate in activity and the last one i.e. zone 3 borders the central vein and was the least supplied with nutrients and oxygen. The hepatocytes of zone 3 were darker stained as compared to zone 2 and 1 . The cytoplasm of hepatocytes was darkly eosinophilic in zone 3 and light in zone 2 and 1 as also reported by Eurell and Frappier (2006) in cattle. 


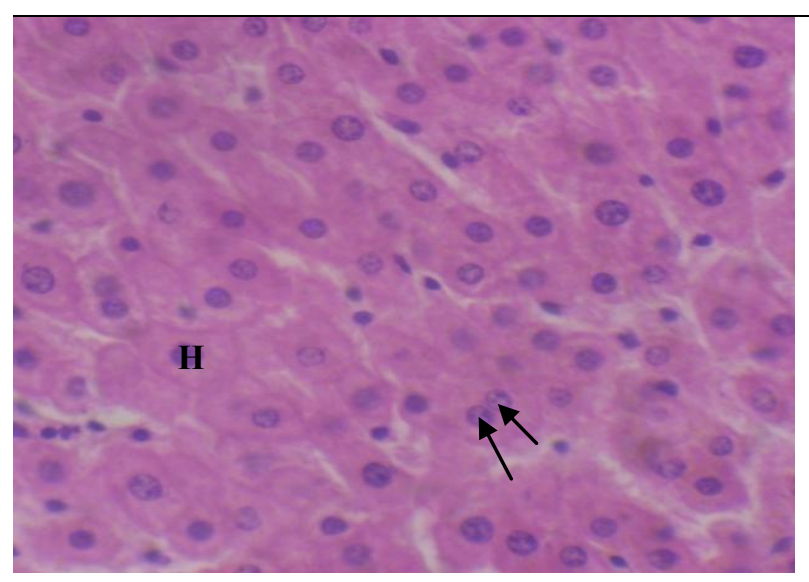

Fig. 9: Photomicrograph of liver showing polygonal hepatocytes (H) with large, centrally located round nuclei and few binucleated hepatocytes (arrow) in adult Bakerwali goat, H\&E, 400X

In both the breeds under study, the liver parenchyma was primarily comprised of hepatocytes (Fig. 9) which appeared as polygonal epithelial cells with abundant eosinophilic, granular cytoplasm and large, centrally located round nuclei as reported by Modekar et al. (2003) in goats and Eurell and Frappier (2006) in cattle. Hepatocyte nuclei contained a prominent nucleolus and scattered clumps of heterochromatin. Occasionally, binucleated hepatocytes (containing two nuclei) were also found in adult Bakerwali goat (Fig. 9) similar to the findings of Pareek (2000) in Magra sheep. Hepatocytes were arranged in radiating cords (hepatic cords) approximately one to two cells in thickness as earlier reported by Pareek (2000) in sheep. This type of pattern of radiating cords was more prominent in Bakerwali goats. In non-descript goats these cords anastomosed with one another showing interconnected network of hepatic arch, enclosing spaces "the sinusoids". Each hepatic cord was supported by fine meshwork of reticular fibres. Pareek (2000) reported one cell thick hepatocytes arrangement in sheep whereas Bevelander and Louis (1961) observed two cell thick hepatocytes arrangement in mammals. The hepatocytes were arranged in cords forming laminae, one cell thick with their free surfaces facing the sinusoids as reported by Bamaniya (2013) in goats.

Every hepatic lobule had central vein which was lined by reticulo-endothelial cells resting on a thin basement membrane and encircled with collagenous and reticular

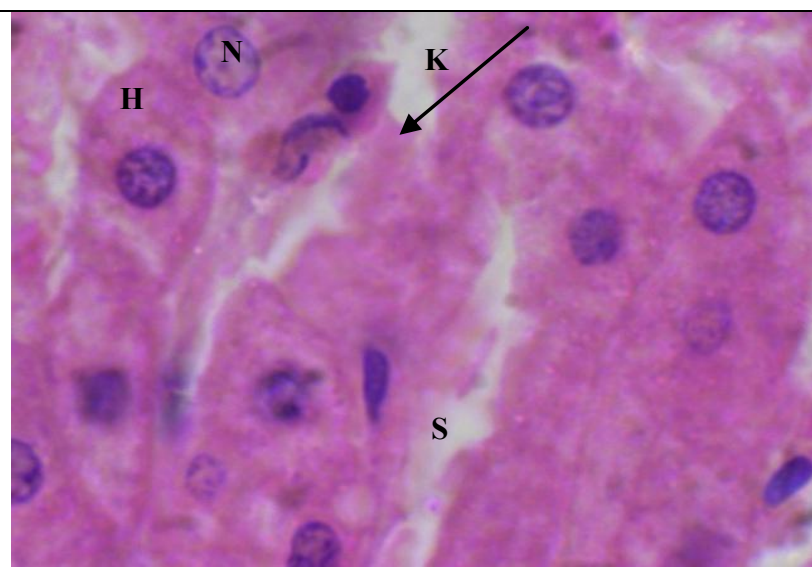

Fig. 10: Photomicrograph of liver showing hepatocytes $(\mathrm{H})$ with round central nuclei $(\mathrm{N})$, sinusoids $(\mathrm{S})$ and kupffer's cell $(\mathrm{K})$ showing slightly indented nucleus. Indentation faces the bulk of the cytoplasm. H\&E, 1000X

fibers irrespective of the breed. The central veins connected with sublobular veins at the periphery of the lobules and communicated directly with sinusoids as reported by Eurell and Frappier (2006) in cattle. The hepatic sinusoids were blood capillaries, located between hepatic cords that courses through the lobule carrying blood from terminal branches of the interlobular hepatic arterioles and interlobular portal venule to the central vein. The sinusoids often communicate with each other via spaces in between hepatocytes and cords through a perisinusoidal space. This arrangement might ensure that each hepatocyte have at least one surface adjacent to a sinusoid. Sinusoids were lined by two types of cells; endothelial cells and stellate marcophages (kupffer cells). The sinusoids in both the breeds of goats were non porous with continuous basal laminae. However, Eurell and Frappier (2006) in goat stated that endothelial lining was discontinuous and a sinusoidal basal lamina was absent. Bamaniya (2013) reported that kupffer's cells (stellate macrophages) were scattered among the sinusoidal endothelial cells in Marwari goat. These specialized cells had a large blue stained nucleus and prominent pink cytoplasm. They appeared as inconspicuous flattened cells or as prominent triangular active phagocytic cells or as rounded cells within sinusoids as darkly stained cells. Nucleus was indented and the indentation was facing the bulk of the cytoplasm (Fig. 10). Similar observations were made by Banks (2007) in domestic mammals. 
In Bakerwali and non-descript goats, the portal vein entered into the liver at a hilus, called the porta, on its visceral surface and finally ended into the sinusoids. It was composed of a prominent internal elastic lamina and endothelium, tunica media was thin and consisted of smooth muscle layer and bundles of collagenous fibers and a prominent tunica adventitia, comprised of layers of smooth muscle cells, collagenous and elastic fibers. The hepatic artery entered into the liver through the hilus and form interlobular hepatic arterioles found in the portal area. These arterioles had a smaller lumen with a thicker muscular wall lined by elastic fibers.

Lymph vessels were also observed in capsule as well as in portal areas along with portal vein and hepatic artery irrespective of the breed as also observed by Pareek (2000) in sheep. The hepatic lymph node was surrounded by a capsule which sends trabeculae into the parenchyma of the node (Fig. 11). The inner portion of capsule and trabeculae contained smooth muscles. The cortex contained sinuses, diffuse lymphatic tissue and lymphatic nodules. A network of fine branching reticular fibres provides a supporting framework for the diffuse and nodular lymphatic tissue. The continuity of the subcapsular sinus with the cortical sinus was also evident. The medulla of lymph node was composed of medullary cords and sinuses as also reported by Eurell and Frappier (2006) in cattle. The medullary sinuses also contained smooth muscle cells. Lymph node was surrounded by loose areolar connective

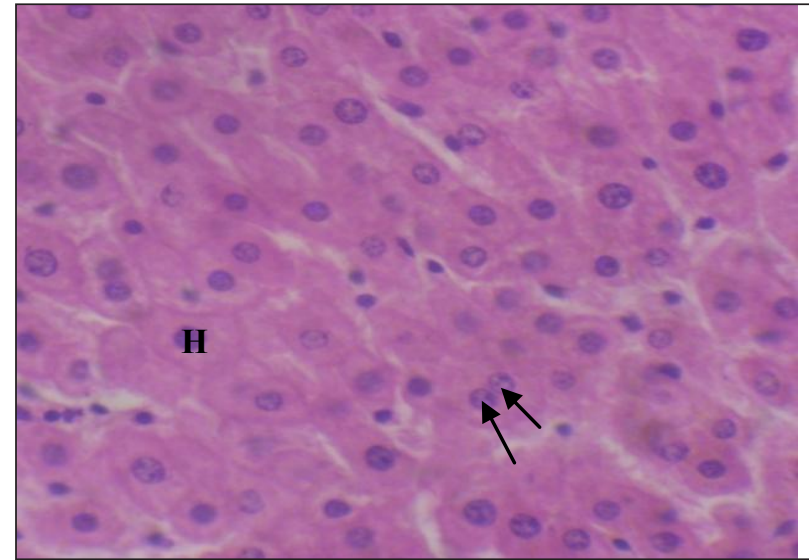

Fig. 11: Photomicrograph of hepatic lymph node showing trabeculae $(\mathrm{T})$ extending from capsule $(\mathrm{C})$ into the cortex, lymphatic nodule, sub-capsular sinus (arrow head) in adult Bakerwali goat, H\&E, 100X

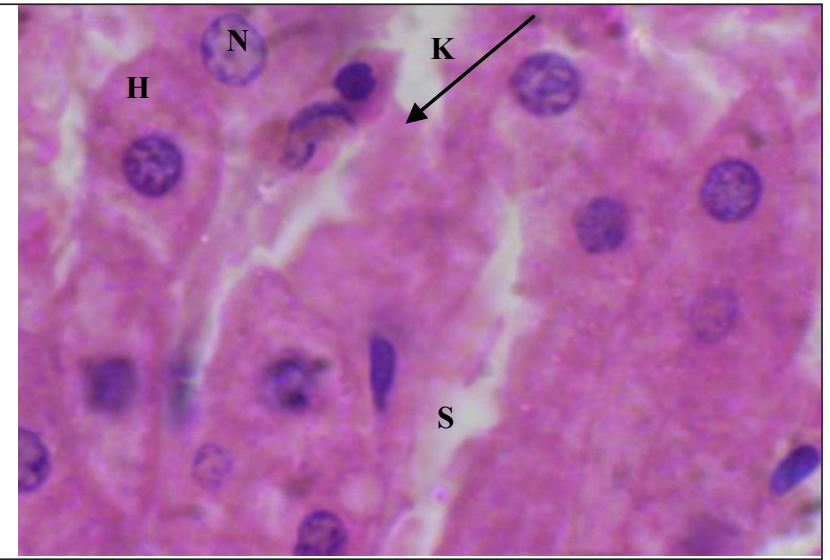

Fig. 12: Photomicrograph of liver showing larger bile ducts (B) lined by simple columnar epithelium with goblet cell $(\mathrm{G})$ and secretions (arrow head) within lumen in adult Bakerwali goat, $\mathrm{H} \& \mathrm{E}, 100 \mathrm{X}$

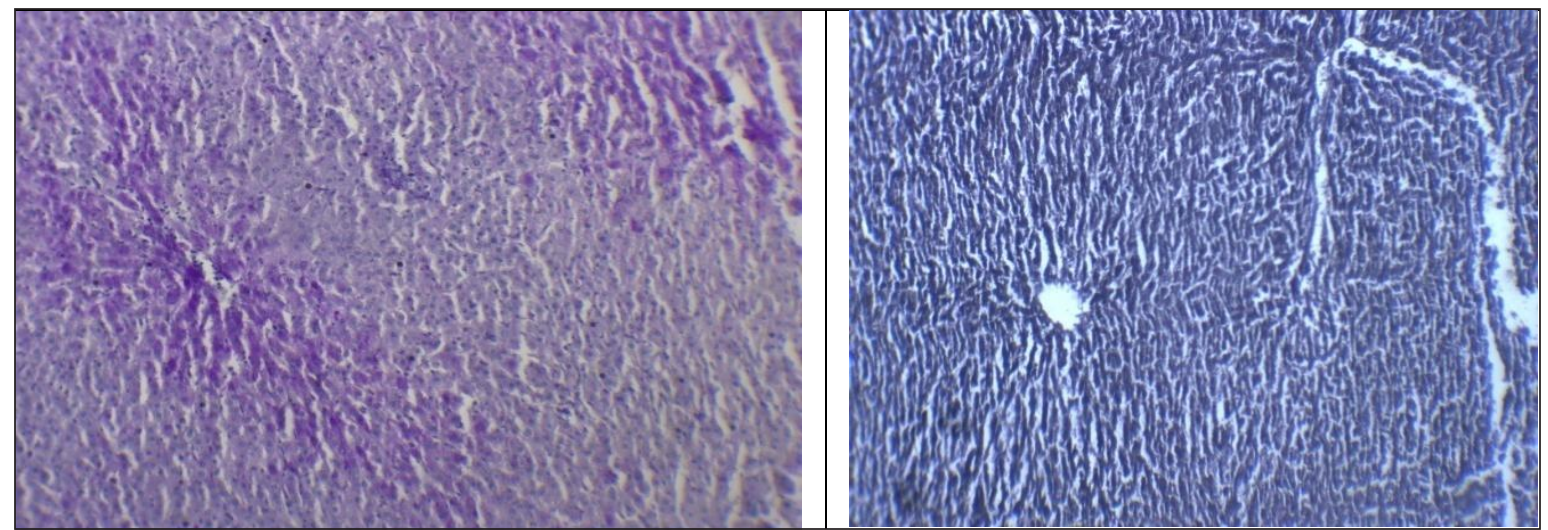

Fig. 13: Photomicrograph of liver showing strong reaction of hepatocytes around central vein (V) to neutral mucopolysaccharides in adult Bakerwali goat, PAS, 1000X
Fig. 14: Photomicrograph of liver showing intense reaction of hepatocytes around central vein (V) to lipids in senile nondescript, sudan black, 1000X 
tissue comprised of fine collagen and reticular fibers and abundant of adipose tissue.

In both the breeds, the small bile ductules were lined by high cuboidal epithelium to simple columnar epithelium. These bile ductules joined to form the large intra-hepatic ducts and finally leave the glands via the main hepatic duct, at the hilus. The bile ductules were located in the portal area with variable size and shape lined with low cuboidal epithelium and closer to lining became oval with nuclei located toward the base. Interlobular bile ducts lined with high cuboidal epithelium converge to form larger intrahepatic ducts, which finally leave the liver lobes through the hepatic ducts. The large bile ducts were lined with ciliated columnar epithelial cells with occasional goblet cells. Apical blebs were evident in all the ducts indicating the secretory activity in both Bakerwali and non-descript goats. The eosinophilic secretory material was seen within lumen of these ductules and ducts (Fig. 12).

Table 1: Table showing histochemical observations in the liver of adult Bakerwali goats

\begin{tabular}{|c|c|c|c|c|c|c|c|c|c|}
\hline \multirow[t]{2}{*}{ Sl. No. } & \multirow[t]{2}{*}{ Stains } & \multirow[t]{2}{*}{ Constituents } & \multirow[t]{2}{*}{ Capsule } & \multirow{2}{*}{$\begin{array}{l}\text { Cytoplasm of } \\
\text { hepatocytes }\end{array}$} & \multirow{2}{*}{$\begin{array}{l}\text { Around } \\
\text { the central } \\
\text { vein }\end{array}$} & \multirow{2}{*}{$\begin{array}{l}\text { In portal } \\
\text { area }\end{array}$} & \multicolumn{3}{|c|}{ Liver acinus } \\
\hline & & & & & & & Zone 1 & Zone 2 & Zone 3 \\
\hline 1 & $\begin{array}{l}\text { Periodic Acid } \\
\text { Schiff's Method }\end{array}$ & $\begin{array}{l}\text { Netural Muco- } \\
\text { polysaccharides }\end{array}$ & + & ++ & +++ & ++ & ++ & ++ & +++ \\
\hline 2 & $\begin{array}{l}\text { Best Carmine } \\
\text { Method }\end{array}$ & Glycogen & - & ++ & +++ & + & + & ++ & +++ \\
\hline 3 & Sudan Black B & Lipids & + & +++ & ++++ & ++ & ++ & +++ & ++++ \\
\hline 4 & Shultz Method & Cholesterol & + & ++++ & +++ & + & +++ & +++ & ++++ \\
\hline
\end{tabular}

Table 2: Table showing histochemical observations in the liver of adult non-descript goats

\begin{tabular}{|c|c|c|c|c|c|c|c|c|c|}
\hline \multirow[t]{2}{*}{ Sl. No. } & \multirow[t]{2}{*}{ Stains } & \multirow[t]{2}{*}{ Constituents } & \multirow[t]{2}{*}{ Capsule } & \multirow{2}{*}{$\begin{array}{l}\text { Cytoplasm of } \\
\text { hepatocytes }\end{array}$} & \multirow{2}{*}{$\begin{array}{l}\text { Around } \\
\text { the central } \\
\text { vein }\end{array}$} & \multirow{2}{*}{$\begin{array}{l}\text { In portal } \\
\text { area }\end{array}$} & \multicolumn{3}{|c|}{ LiveCr acinus } \\
\hline & & & & & & & Zone 1 & Zone 2 & Zone 3 \\
\hline 1 & $\begin{array}{l}\text { Periodic Acid } \\
\text { Schiff's Method }\end{array}$ & $\begin{array}{l}\text { Netural Muco- } \\
\text { polysaccharides }\end{array}$ & + & ++ & +++ & ++ & ++ & ++ & +++ \\
\hline 2 & $\begin{array}{l}\text { Best Carmine } \\
\text { Method }\end{array}$ & Glycogen & - & ++ & +++ & + & + & ++ & +++ \\
\hline 3 & Sudan Black B & Lipids & + & +++ & ++++ & ++ & ++ & +++ & ++++ \\
\hline 4 & Shultz Method & Cholesterol & + & ++++ & +++ & + & +++ & +++ & ++++ \\
\hline
\end{tabular}


hepatocytes showed weak reaction and below the portal vein in male where hepatocytes showed intense reaction.

The cytoplasm of hepatocytes showed moderate reaction for neutral muco-polysaccharides (PAS), moderate reaction for glycogen (Best carmine) and strong reaction for lipids (Sudan black) in both breeds of goats (Bakerwali and non-descript goats). As also reported by Thakur (2020) in buffalo, hepatocytes showed intense reaction in all regions for PAS except at apex of caudate lobe in female where hepatocytes showed weak reaction and below the portal vein in male where hepatocytes showed intense reaction. Modekar et al. (2003) in goat liver observed mild positive PAS reaction in hepatocytes and moderate reaction for glycogen. The hepatocytes of buffalo liver showed high reactivity to the amount of glycogen by best's carmine method and PAS which also stained the neutral mucopolysaccharide and this referred to the normal function of the liver in synthesis of glycogen from glucose and storing it in the hepatocytes upon somatic demand. Similar findings were reported by Banks (2007).

Around the central veins, the neutral muco-polysaccharides (PAS) showed strong reaction for glycogen (Best carmine) and for lipids (Sudan black) showed intense reaction in both breeds of goats (Bakerwali and non-descript goats) (Fig. 13, 14). As also reported by Thakur (2020) in buffalo, Hepatocytes showed intense reaction in all regions for PAS except at apex of caudate lobe in female where hepatocytes showed weak reaction and below the portal vein in male where hepatocytes showed intense reaction. PAS and Best's carmine to central vein gave positive results for carbohydrates as also reported by Rashad et al. (2017) in fresh buffalo. Modekar et al. (2003) in goat liver observed mild positive PAS reaction around central vein and moderate reaction for glycogen.

\section{CONCLUSION}

It can be concluded that irrespective of breed, liver consist of hepatic lobules, portal lobules and liver acini. Hepatic lobule was hexagonal with clear boundaries in Bakerwali goat whereas in non-descript goats, the interlobular connective tissue was minimal making it difficult to recognize the lobule as hexagonal. Liver acini were diamond-shaped area having three zones. Hepatocytes were arranged in radiating cords (hepatic cords) which were prominent in Bakerwali goats but in non-descript goats these cords anastomosed with one another showing interconnected network of hepatic arch, enclosing spaces "the sinusoids". The histochemical distribution of mucopolysaccharides, proteins and sudanophilic lipids didn't vary in different age groups of Bakerwali and nondescript goats but reactions was variable in different parts of liver parenchyma.

\section{REFERENCES}

Arora, R., Bhojak, N. and Joshi, R. 2013. Comparative aspects of goat and cow milk. Inter. J. Eng. Sci. Inven., 2(1): 7-10.

Bamaniya, M. 2013. Gross and Histological studies on the liver of Marwari goat (Capra hircus). M.V.Sc thesis, submitted to Rajasthan university of veterinary and animal sciences, Bikaner.

Banks, W. J. 2007. Text Book of Applied Veterinary Histology. $4^{\text {th }}$ ed. Baltimore: Williams \& Wilkins, pp. 362-72.

Bevelander, G. and Louis S.T. 1961. Essentials of histology. The C.V. Mosby Company, United States of America, pp. 187200.

Culling, C.F.A. 1974. Handbook of histopathology and histochemical technique, $3^{\text {rd }}$ edition, Butterworths \& Co.Ltd. pp. 302.

Dyce, K.M., Sack, W.O. and Wensing, C.J.G. 2010. The Text book of Veterinary Anatomy, $4^{\text {th }}$ Edn., W.B. Saunder's Company, Philadelphia, pp. 135-136.

Eurell, J.A. and Frappier, B.L. 2006. Dellmann's Textbook of Veterinary Histology, $6^{\text {th }}$ Edition Wiley Blaclwell, pp. $201-$ 206.

Frandson, R.D., Wilke, W.L. and Fails, A.D. 2009. Anatomy and Physiology of Farm Animals, $7^{\text {th }}$ Edition.

Gupta, J.L. and Bakshi, S.B. 2009. Sheep development in temparate region. Yak book publishers, Jammu, pp: 151-153.

Hu, W., Ye, T., Yang, Y., Liu, B. and Zheng, W. 2020. Effects of transport stress on pathological injury and expression of main heat shock proteins in the caprine stomach. BMC Vet. Res., 16: 347.

Iqbal, A., Khan, B.B., Tariq, M. and Mirza, M.A. 2008. Goat-A Potential Dairy Animal: Present and Future Prospects. Pak. J. Agri. Sci., 45(2): 227-230.

Khan, M., Prasad, J. and Sinha, R.D. 1989. Histology of the liver of black bengal goats. Ind. J. Ani. Sci., 59(2): 244-246.

Luna, L.G. 1968. Manual of histological staining methods of armed force institute of pathology. $3^{\text {rd }}$ edn. McGraw-Hill Book Company, New York. pp: 87-88, 94-95. 
Madhan, K.E. and Raju S. 2014. Comparative histology of human and cow, goat and sheep liver. J. Surg. Acad., 4(1): 10-13.

Mariappa, D. 1981. Studies on the histology of the bovine liver. Ind. Vet. J., 58: 24-26.

Modekar, S.S., Bhosle, N.S. and Mamde, C.S. 2003. Morphological study of liver in Osmanabadi goat (Capra hircus). Ind. J. Vet. Anat., 15(1/2): 65-67.

Pareek, P. 2000. Gross and histological studies of the liver in Magra Sheep (Ovis aries) M.V.Sc. Thesis, College of Veterinary and Animal Science Rajasthan Agricultural University, Bikaner, pp. 1-78.

Prunescu, C.C., Prunescu, P., Krasińska, M. and Krasiński, Z.A. 2002. Liver histological structure in adult European bison. Bison bonasus (Linnaeus, 1758) Folia Morphol., 61(3): 137142.

Rashad E., El-Haback H.A., Rabou M.I.A., Hussein S, and Khalifa E.F. 2017. Gross anatomy and morphology of Egyptian water buffalo's liver (Bubalus Bubalis) with reference to some histochemical and immunohistochemical evaluation. Res. J. Pharma. Biol. Chem. Sci., 8(3): 45-60.
Sarma, K., Suri, S., Devi, J. and Doley, P.J. 2012. Morphological studies on the mouth cavity of Bakerwali goat (Capra hircus) of Jammu region. Ind. J. Vet. Anat., 24: 20-21.

Singh, S.K., Singh, M.K. and Singh, N.P. 2006. Role of goats in sustainable rural livelihoods in India. In "Goats-Undervalued Assets in Asia". Proceedings of the aphca- Ilri regional workshop on goat production systems and markets. Luang prabang, Lao PDR, 24-25.

Thakur, P.N. 2020. Histochemical studies of liver in Buffalo (Bubalus bubalis). Buff. Bull., 39(2): 139-144.

Trautmann, A. and Fiebiger, J. 1957. Fundamentals of the Histology of Domestic Animals. Comstock Publishing Associates Ithaca, New York, pp. 219-224. 
